\title{
Improving Students' Creativity in Video Making by Problem Based Learning Model
}

\author{
Supri Wahyudi Utomo ${ }^{1}$, Moh. Ubaidillah², Soetarno Joyoatmojo ${ }^{3}$, Sri Yutmini ${ }^{4}$, Nunuk Suryani ${ }^{5}$
}

\begin{tabular}{l} 
ARTICLE INFO \\
\hline Article History: \\
Received 01.01 .2019$. \\
Received in revised form \\
29.04 .2019 \\
Accepted \\
Available online 01.07 .2019
\end{tabular}

\begin{abstract}
This research is motivated by the lack of students' creativity on video making in Multimedia subject of Accounting Department. This is caused by the less precise learning model chosen by the teacher. Video making in Multimedia subject is very essential as students are encourage to be able to create media in teaching in order to make the students understand the materials easily. This research is meant to improve students' creativity in video making in Multimedia subject by using problem based learning model. The research used Pre-Experimental Design with One Shot Case Study. This study used quote sampling as the sampling technique and obtained as many as 41 students from the $4^{\text {th }}$ semester of Accounting Education Department. The data were collected through questionnaires and student learning outcomes. The data were then analyzed by using structural equation modeling (SEM) and partial least squares (PLS) tool. The results showed that the problem-based learning model positively influenced the improvement of creativity in video making. Furthermore, the value of student learning achievment is more than 70 .
\end{abstract}

(C) IJERE. All rights reserved

Keywords: ${ }^{1}$

Problem Based Learning, Creativity, Video

\section{INTRODUCTION}

The learning paradigm undergoes a shift from teacher-centered learning into a student-centered learning (Anyanwu and Iwumadi, 2015). The paradigm shift demands changes in the learning process. The change contains consequences that learning no longer uses conventional models with lecture methods. Learning model should enable active involvement of learners, especially for college students in order to prepare them to face the pressure of their job in the work place and win the competition. Thus, knowledge and experience are no longer enough to make them survive. While university has provided students with abundant of knowledge and workplace experience, the global era has confirmed that those are no longer enough to make the university graduates survive. Innovation is needed and the ability to innovate is creativity. The need for educational innovation is important. Innovation can be directed to progress in one, several, or aspects of the education system: theory and practice, curriculum, teaching and learning, policy, technology, institutions and administration, institutional culture, and teacher education (Serdyukov and Serdyukov, 2017). in reviewing innovation, we must think of new ideas that require a certain level of creativity, are willing to be involved in risk, and bring that idea to fruition (Glassman, Opengart and Glassman, 2016). Creativity is something that needs to be trained and nurtured trough innovative learning which enhances students' higher order thinking skills that can develop students' creativity. Therefore, traditional learning with lecture methods is no longer relevant to the demands of 21st century as it is incapable of equipping higher order thinking skills. Students need to be actively involved in every activity of learning and they have to be able to solve any problem that arises. One way to achieve this goal is through Problem Based Learning model as how Michael and Modell (2003) had said that students need to be actively involved in the whole learning process and therefore, students' center learning is the most relevant. One of the learning models that prioritizes the activities of learners is problem-based learning. This is especially important for the multimedia subject as this subject requires students to innovate. Multimedia needs students' creativity to create interesting media especially in accounting subject in which most of the

\footnotetext{
1 supriutomo@yahoo.co.id; orcid.org/0000-0003-1991-4710

2 mohubaidillah@unipma.ac.id; orcid.org/0000-0002-2488-9575

3 soetarno486311@gmail.com; orcid.org/0000-0002-6846-5723

4 denbeipalestrina@gmail.com

5 nunuk_suryani_uns@yahoo.com

Sebelas Maret University 1,3,4,5, Universitas PGRI Madiun 2
} 
materials require memorizing. Creative innovation to create learning media which allows students to easily understand the materials is badly needed. The media used must be able to grow student motivation, it is also used to facilitate students in receiving learning delivered (Nirbita, Joyoatmojo and Sudiyanto, 2017). Combining all the matters above, the most suitable teaching method to enhance students' creativity in Video making is proposed by the researcher which is Problem Based Learning Method.

\section{Situation of the Problem}

Previous studies which are relevant to the problem-based learning model and aimed at improving the achievement of learners have actually been carried out by previous researchers, among others are: 1) The use of Computer Based Learning Media and Innovative Attitudes toward Learning Outcomes of Information and Communication Technologies (Abrianto and Sitompul, 2014) which describes the advantages of using streaming radio learning media compared to computers in influencing ICT learning outcomes by using quasi experimental research methods; 2) The Influence of Computer Based Learning Media to Mathematics Learning Achievement Viewed from Student Learning Activity (Setyono, 2016) which describes the effect of macromedia flash 8 or powerpoint on students' achievement which include the influence of high, medium, and low activeness to student's learning achievement by using quasi experimental methods; 3) The Effect of Using Computer Based Learning on Learning Activity and Learning Achievement in ISBD Courses at STKIP Garut (Sofiah, 2005) which describes the use of the PowerPoint media which is very helpful for teachers in delivering theoretical materials in classical learning / group learning. Classical learning / group learning are similar to ISBD courses with the creativity of teachers with mixed lecture material can combine all elements of media such as text, video, animation, image, graphics and sound into an interesting entity that can accommodate students who have visual, audio and kinesthetic; 4) The Influence of Using Internet Based Learning Information Technology to Student Learning Interest of Class VIII SMPN 30 Semarang in the Academic Year of 2011/2012 (Nurfahmi, 2012) which explained about information technology which is very influential in supporting learning process. Information technology used in the learning process is the internet. The Internet is considered to increase students' interest in learning in school; 5) The Effectiveness of Multimedia Learning Tools in Education (Almara'beh, Amer, \& Sulieman. 2015) explained about the important of using multimedia in teaching including video. The result shows that the use of video can increase students' interest in learning which in turn also improve their achievement ; 6) Creative and Critical Thinking Skills in Problem-based Learning Environments (Birgili, 2015) which explained the role of Problem Based Learning on improving students creativity. The process that students have to go trough in PBL especially sintesizing, hypnotizing, analyzing and problem solving can help students to be more creative in solving problem through various possibilities ; 7) The Role of PBL in Improving Physics Students' Creative Thinking and Its Imprint on Gender (Eldy, Elnetthra F \& Sulaiman, F, 2013) which explained how important PBL in improving students' creativity. Some aspect of creativity that can be improved through PBL such as fluency, flexibility and originality.

In relation to the results of this study, none of them discussed about the influence of problem-based learning model on improving the creativity of video making in multimedia subjects. Therefore, the authors are interested in discussing about the learning model that can improve students' creativity, where the researchers are trying to apply the problem-based learning model, because by applying the learning model students are given the freedom to be creative. The purpose of this study is to determine the effect of problem-based learning model on students' creativity in making video and students' learning outcomes.

\section{Aim of the Study}

Creativity has become an important issue to be addressed by educators in recent years. This is due to the development of the world especially the economic development which demands people to be able to innovate. Moreover, the education system which has gone through some important shift from teacher center to students' center learning has demanded teacher to do some innovation in teaching methods. Based on those problems, the researcher attempted to answer some questions namely how effective is Problem Based learning in improving students' creativity especially in video making of Multimedia subject. This research is also meant to analyze how significant is the impact of PBL on improving students' understanding and achievement. 


\section{METHOD}

\section{Study Approach}

This research uses quantitative approach. The research used Pre Experimental Design with One-Shot Case Study. Quantitative methods are used through the dissemination of questionnaires and written tests. The data are collected through questionnaires and performance to obtain learning outcomes. Questionnaires are distributed to the respondents then the answers given by the respondents are tabulated and processed (Punch, 2009).

\section{Study Sample}

This research was conducted at Universitas PGRI Madiun in March 2017 to June 2017. The populations in this study are all students of accounting education from 4th semester and the sample in this study are taken from class $C$ and D as many as 41 students (7 male and 34 female) with quota sampling method.

\section{Source of Data}

Data used in this study are collected from student learning outcomes and questionnaires. Learning outcomes are used to determine the successful application of problem-based learning models in improving students' achievement and creativity in making video. Questionnaires are used to find out the students' responses about the learning process using a problem-based learning model especially in improving their creativity.

\section{Research Cycle}

The steps in this research are first lecturer oriented students to the problem by assigning students to create video related to the topic given to every group. The topic assigned to every one group is different from others. Second, the students are assigned to created study groups, which consist of 2 students for each group. Third, the students then identify the problem related to the topic and finding possible solution on how they should create their videos which contain the material assigned. Fourth, students discuss the problem and its possible solution with the group member and lecturer. During the discussion, the students were allowed to ask question related to their ideas and get some advices from the lecturer.

Fifth, the video making process should be completed after the discussion and feedback from lecturer through these process: 1) upon receiving the topic of the material, students analize the content of the topic; 2) students then find the materials and simplify them to be inserted in the video content;3) students consult the result of the first discussion to the lecturer;4) the students then determine the format and content of the video as well as time allocation if finishing the video; 5) students then create their video and do the editing process; 6) after they have created their video, they have to present the result in the classroom. During the whole process of video making, the students are allowed to consult the lecturer related to any difficulty they faced. Some problems that they may ask are: their role in the video, should they include themselves in the video and how the video format should be.

Sixth, in completeing the video, students present the video in the class. Last, the lecturer evaluates the video creation results based on the creativity of the video and its relevance to the topic and sub topic given as well as provide some feedback to the students. After the presentation and evaluation, the students were given some questionnaire related to the method used by the lecturer. The questionnaires were then evaluated as another source of data for the research.

\section{FINDINGS}

Based on the learning outcomes and questionnaires distributed to students after Multimedia Computer Based Learning class by applying problem-based learning model, the data can be observed as follows.

\section{Students' Learning Outcome}

Student learning outcomes consisting of tasks, midterms and semester ends are cumulative. Here are the results of student learning. 
Table 1

Students' Learning Outcome

\begin{tabular}{ccccc}
\hline Score & \multicolumn{2}{c}{ Class } & Total & $\%$ \\
\hline $90-100$ & C & D & 2 & $5 \%$ \\
\hline $80-89$ & 1 & 1 & 29 & $71 \%$ \\
\hline $70-79$ & 15 & 4 & 10 & $24 \%$ \\
\hline $60-69$ & 6 & & 0 & $0 \%$ \\
\hline $50-59$ & & & 0 & $0 \%$ \\
\hline Total & & 19 & 41 & $100 \%$ \\
\hline
\end{tabular}

Source: processed data (2017)

Table 1 shows the learning outcome of 41 students consisting of class $C$ amounted to 22 students and class D amounted to 19 students. The high score of 2 students with the value of 90-100, the value of 80-89 with the number of 29 students and the value of 70-79 as many as 10 students, this indicates that all students pass in accordance with the predefined passing criteria with a minimum value of 70 .

\section{Questionnaire}

\section{Evaluation of Measurement Model (Outer Model)}

Outer model is a step to know the validity and reliability that connects with latent variables on the effect of PBL on students' creativity in making video in multimedia subject. Some aspects being measured are flexibility, fluency, originality, usefulness and so on according to the indicators of creativity. The validity is measured by using outer loading and AVE. Requirements to meet validity must be above 0.50. Outer loading measurements have 6 invalid indicators ABMD5, MKP16, PMPBI17, PMPBI18 and PMPBI20. On the AVE measurement all contracts and dimensions meet the criterion of the criteria of 0.5 are therefore valid.

Reliable measurements use composite reliability with criterion of 0.7. Results by the smart PLS show that all the constants and dimensions have met the criteria, so declared the reliability of all the constants and dimensions. Here are the AVE tables and composite reliability.

Table 2 AVE dab Composite Reliability

\begin{tabular}{|c|c|c|}
\hline \multicolumn{2}{|c|}{ AVE } & \multirow{2}{*}{$\begin{array}{r}\text { Composite Reliability } \\
0.911899\end{array}$} \\
\hline ABMD & 0.53617 & \\
\hline KRTV & 0.50605 & 0.92439 \\
\hline MKP & 0.709 & 0.904535 \\
\hline PBL & 0.68553 & 0.867215 \\
\hline PBM & 0.53432 & 0.940099 \\
\hline PBO & 0.64297 & 0.782657 \\
\hline PBT & 0.59075 & 0.850463 \\
\hline PBW & 0.74487 & 0.897062 \\
\hline PMPBI & 1 & 1 \\
\hline
\end{tabular}

Source: the processed data of SmartPLS 2 (2017)

\section{Model Structure (Inner Model)}

The structural model is evaluated by using $R$-square $\left(R^{2}\right)$ for the dependent construct, and $t$ test as well as the significance of the structural path parameter coefficients. $R^{2}$ can be used to assess the effect of independent latent variables on latent dependent variables on whether they have substantive effects. In Table 4, it shows that the lowest $R$ Square of 0.42724 is include into sufficient category and the highest is 0.946530 as strong category.

Table 3 R-Square

\begin{tabular}{cc}
\hline & R-Square \\
\hline ABMD & 0.94653 \\
\hline KRTV & 0.93391 \\
\hline
\end{tabular}




\begin{tabular}{cl} 
MKP & 0.90144 \\
\hline PBL & 0.80697 \\
\hline PBM & \\
\hline PBO & 0.62895 \\
\hline PBT & 0.92862 \\
\hline PBW & 0.65009 \\
\hline PMPBI & 0.42724 \\
\hline
\end{tabular}

Source: the result of SmartPLS processed data (2017)

\section{Evaluation of the Goodness of Fit}

This analysis is done to determine whether the hypothesis fit the result of the study. The calculation of goodness of fit value of 0.717142943 above criteria 0.5 so that the model of this study is categorized as fit. Here is the result of goodness of fit calculation with the formula:

$$
\begin{aligned}
& \text { Gof }=\sqrt{\text { AVE X R-Square }} \\
& \text { Gof }=\sqrt{0,661070 \times 0,777968} \\
& \text { Gof }=\sqrt{0,514294} \\
& \text { Gof }=0,717142943
\end{aligned}
$$

\section{Significance Test}

In table 6 it can be seen the effect of problem-based learning model (PBM) to student creativity (KRTV) with a Tstatistic value of 111.732096 above 1.96 or significant 5\%, and the coefficient of 0.96639 as the basis shows the number of positive numbers. This shows that the constraint of problem- based learning model has a positive effect on student creativity.

Table 6 Route Coefficient and T-Statistics

\begin{tabular}{lrrrrr}
\multicolumn{1}{c}{ Konstrak } & $\begin{array}{c}\text { Original } \\
\text { Sample (O) }\end{array}$ & $\begin{array}{c}\text { Sample } \\
\text { Mean (M) }\end{array}$ & $\begin{array}{c}\text { Standard } \\
\text { Deviation } \\
\text { (STDEV) }\end{array}$ & $\begin{array}{c}\text { Standard } \\
\text { Error (STERR) }\end{array}$ & $\begin{array}{c}\text { T Statistics } \\
\text { (|O/STERR|) }\end{array}$ \\
\hline KRTV -> PBL & 0.89831 & 0.90103 & 0.01789 & 0.01789 & 50.2063 \\
\hline KRTV -> PBO & 0.79306 & 0.79811 & 0.02924 & 0.02924 & 27.12682 \\
\hline KRTV -> PBT & 0.96365 & 0.96471 & 0.00576 & 0.00576 & 167.3479 \\
\hline KRTV -> PBW & 0.80628 & 0.80758 & 0.03775 & 0.03775 & 21.35895 \\
\hline PBM -> ABMD & 0.9729 & 0.97336 & 0.00424 & 0.00424 & 229.3547 \\
\hline PBM -> KRTV & 0.96639 & 0.96601 & 0.00865 & 0.00865 & 111.7321 \\
\hline PBM -> MKP & 0.94944 & 0.95016 & 0.00673 & 0.00673 & 141.0184 \\
\hline PBM -> PMPBI & 0.65364 & 0.65762 & 0.04594 & 0.04594 & 14.22723 \\
\hline
\end{tabular}

Sumber: the result of SmartPLS data processed (2017)

\section{RESULT, DISCUSSION, AND SUGGESTIONS}

The result of student learning showed that the applications of problem-based learning model can improve learning achievement. The average student learning achievment is above 70 . The result shows that the students are able to create video with interesting content and relevant to the topic. Moreover, their video also has quite high quality in term of creative and interesting content. The video are very contributive to the learning process too. Proven by how their peers can easily understand the material content through the video made by each groups. It can be explained that students are required to solve the problem and given the freedom (creative and innovative) in making video

Provided by lecturers so that students become more intense in searching for references related to the problems they encountered. Therefore, students will automatically be creative and innovative in making 
video and students can easily create creative videos as they are required to make their classmates understand the content of the material through the video they have made.

The results of questionnaire data show that the problem-based learning model positively affects the creativity of students in making the video. It can be explained that students are required to solve problems with video media. Therefore, students are automatically analyzing problems and discuss with their group members to find solutions and be creative and innovative in making videos so that students' creativity grows. The use of Problem Based Learning model can improve students' creativity and learning outcomes in the making of video.

This is in accordance with the theory of creativity according to Suharyadi, Nugroho, Purwanto, and Faturohman (2008 p 92) stating that the ability to develop new ideas and new ways of solving problems and finding new thinking. Creativity is something that can be highly valued or not valued at all because there is no general purpose approval of its meaning, although it has a broad term. Creativity is the most valuable asset a person has for continued evolution (Brand, Handy \& Harrison, 2015).

Rhodes as cited in Munandar (1985 p 1) mentions there are 4 (four) characteristics of creativity as follows: a) Person, is the uniqueness of the individual in mind and expressions; b) Process, ie smoothness, flexibility, and original thinking; c) Press, is a situation of life and social environment that gives impetus to display creative actions, and d) Product, defined as the ability to produce new and original work and meaningful to the individual and the environment.

Creativity can be trained and developed through learning or habituation. Creativity needs to be designed, because creativity is the software-and the brain is the hardware, creativity needs to be installed through habituation. (TimWesfix, 2013). A person's ability to be creative and produce innovative solutions is closely related to the memory structure and learning ability. According to Bertoncelli, Mayer \& Lynass (2016 p 195), from an industry point of view, creativity has become one of the greatest drives in business innovation and tools and techniques have been widely studied and practiced in large companies over the last few decades.

Creativity according to Suharyadi, Nugroho, Purwanto, and Faturohman (2008 p 92) is the ability to develop new ideas and new ways of solving problems and finding new thinking. Creativity is something that can be valued high or not valued at all because there is no general purpose approval of its meaning, although it has a broad term. Creativity is the most valuable asset a person has for continued evolution (Brand, Handy \& Harrison, 2015).

The results of the research also supported by Aktamis \& Ergin research (2008 p11) which shows that students who are given the freedom to solve the problems they faced have a much higher level of creativity than students taught using traditional methods and approaches. Students become creative and innovative thinking to solve problems. The results of the preliminary study (Ayob, Hussain, Mustafa, \& Shaarani, 2011) also show that students' creativity dimensions have been nurtured and refined as a result of problem-solving processes involved in experiential learning activities. A creative approach to problem solving will in turn produce innovative solutions.

The Implementation of problem-based learning model on the subject of multimedia computer-based learning program of accounting education of 4th semester in class C and D FKIP of Universitas PGRI Madiun in the academic year of 2016/2017, can be concluded that the application of problem-based learning model positively affect the creativity of students in making video in the course of action. The implementation of problem-based learning model on the subject of multimedia computer-based learning that the value of students achievment more than 70 .

The course of Multimedia Computer Learning consists of power point, word, blog, video and SPSS. Suggestions in this research are Power point and Word courses need to be deleted from Computer Based Learning Multimedia course and put into Application of Computer subject because video and material making need at least five meetings. The limitation of this study is that the sample used is too small. further research is needed by using a larger sample to see the consistency of the results. 
Utomo,S.W., Ubaidillah,M., Joyoatmojo,S., Yutmini,S. \& Suryani,N. (2019). Improving students' creativity in video making by problem based learning model. International Journal of Educational Research Review,4(3),481-488.

\section{REFERENCES}

Abrianto, D. \& Sitompul, H. (2014). Penggunaan Media Pembelajaran Berbasis Komputer dan Sikap Inovatif terhadap Hasil Belajar Teknologi Informasi dan Komunikasi. Jurnal Teknologi Informasi \& Komunikasi dalam Pendidikan, 1 (1), 1-13.

Aktamis, H., \& Ergin, O. (2008). The effect of scientific process skills education on students' scientific creativity, science attitudes and academic achievement. Asia-Pacific Forum on Science Learning and Teaching. 4, 1-21

Almara'beh, Hi., Amer, Ehab F. \& Sulieman, A. (2015). The effectiveness of multimedia learning tools in education. International Journal of Advanced Research in Computer Science and Software Engineering. 5, 761-764

Anyanwu, S. E. \& Iwumadi, F. N. (2015). Student-centered teaching and learning in higher education: transition from theory to practice in Nigeria. International Journal of Education Research, 3 (8), 349358.

Ary, D., Jacobs, L.C., Sorensen, C., \& Walker, D.A. (2014). Introduction to research in education. Belmont. Wadsworth, Cengage Learning.

Ayob, A., Hussain, A., Mustafa, M. M., \& Shaarani, M. F. A. S. (2011). Nurturing creativity and innovative thinking through experiential learning. Procedia Social and Behavioral Sciences, 18, 247-254.

Bacanl, H., Dombay, M. A., Demir, M., \& Tarhan, S. (2011). Quadruple thinking: creative thinking. Procedia Social and Behavioral Sciences. ScienceDirect, 12, 536-544.

Bertoncelli, Tiziana, Oliver M., \& Mark L. (2016). Creativity, learning techniques and TRIZ. Procedia CIRP, 39, $191-196$.

Birgili, B. (2015). Creative and critical thinking skills in problem-based learning environments. Journal of Gifted Education and Creativity, 2 (2), 71-80.

Brand, G., Handy, L., \& Harrison, R. (2015). Mining the gap! Fostering creativity and innovative thinking. Procedia-Social and Behavioral Sciences. ScienceDirect, 20, 79-84.

Eldy, Elnetthra F. \& Sulaiman, F. (2013). The Role of PBL in improving physics students' creative thinking and its imprint on gender. International Journal of Education and Research, 1, 1-10.

Fahmi, I. (2013). Kewirausahaan Teori, Kasus dan Solusi. Jakarta: Alfabeta

Graham, T. \& Berry, J. (1992). Using video in the teaching of mathematics. Mathematics Association. Jstor, 21, 19-21, http://www.jstor.org/stable/30214878.

Glassman, A. M., Opengart, R. and Glassman, A. M. (2016). Teaching innovation and creativity : Turning theory into practice'. Journal of International Business Education, 11 (1), 113-132.

Gorghiu, G., Draghicescu, L. M., Cristea, S., Petrescu, A. M., \& Gorghiu, L. M. (2015). Problem-based learning-an efficient learning strategy in the science lessons context. Procedia-Social and Behavioral Sciences. ScienceDirect, 191, 1865-1870.

Harun, N. F., Yusof, K. M., Jamaludin, M. Z., \& Hassan, S. A. H. S. (2015). Motivation in problem-based learning implementation. Procedia-Social and Behavioral Sciences. ScienceDirect, 56, 233-242.

Huang, Samuel D. \& Aloi, J. (20141). The impact of using interactive video on general bioloy. National Association of Biology Teacher. University of California press, 53, 281-284

Kholida, D. (2015). PengaruhPenggunaan Model Pembelajaran Problem Based Learning terhadap Motivasi Belajar Sejarah Siswa Di kelas XI Madrasah Aliyah Negeri 2 Jepara. Skripsi. Jurusan Sejarah Fakultas Ilmu Sosial Universitas Negeri Semarang.

Michael, J.A. \& Modell. H.I. (2003). Active learning in secondary and college science classrooms : A working model for helping the learner to learn. London. Lawrence Erlbaum Associates, Publishers. 
Utomo,S.W., Ubaidillah,M., Joyoatmojo,S., Yutmini,S. \& Suryani,N. (2019). Improving students' creativity in video making by problem based learning model. International Journal of Educational Research Review,4(3),481-488.

Mudlofir, A. \& Rusydiyah, E.F. (2016). Desain Pembelajaran Inovatif dari Teori ke Praktik. Jakarta: Raja Grafindo Persada.

Munandar, U. (1985). Mengembangkan Bakat Dan Kreativitas Anak Sekolah. Jakarta: PT.Greamedia.

Nirbita, B. N., Joyoatmojo, S. \& Sudiyanto, S. (2017). Learning media based on ict for learning strategy of accounting program in vocational school. Advances in Social Science, Education and Humanities Research, 116, 58-61.

Nurfahmi, Q. (2012). Pengaruh Penggunaan Teknologi Informasi Pembelajaran Berbasis Internet terhadap Minat belajar PAI Siswa Kelas VIII SMPN 30 Semarang Tahun Pembelajaran 2011/2013. Jurnal Ilmiah SINUS, 15 (1), 71-83

Phungsuk, R., Viriyavejakul, C. \& Ratanaolarn, T. (2017). Development of a problem- based learning model via a virtual learning environment. Kasetsart of Journal Social Sciences, 1 (10).

Punch, K. F. (2009). Introduction to research methods in education. Los Angeles: Sage Publishing.

Rahman, S., Yasin, R. M., Buang, N. A., Oganisjana, K., Fernate, A., \& Koke, T. (2015). Using problemfocused approach to nurture creativity and entrepreneurship among students. Procedia-Social and Behavioral Sciences. ScienceDirect, 191, 2782-2786.

Sage, Sara \& Torp, L. (2002). Problems as possibilities: problem-Based learning for K-16 Education. Virginia. Association for Supervision and Curriculum Development.

Saliceti, F. (2015). Educate for creativity: New educational strategies. Procedia-Social and Behavioral Sciences. ScienceDirect, 197, 1174-1178.

Setyono, I. D. (2016). Pengaruh Media Pemebelajaran Berbasisi Komputer terhadap Prestasi Belajar Matematika: Prosididng Konferensi Nasional Penelitian Matematika dan pemebelajarannya (KNPMPI) Universitas Muhammadiyah Surakarata, 12 Maret 2016.320-328

Sofiah, E. (2005). Pengaruh Pemanfaatan Media Pembelajaran Berbasis Komputer terhadap Aktivitas Belajar dan Prestasi belajar dalam Mata Kuliah ISBD DI STKIP Garut. Jurnal Wawasan Ilmiah, 5 (10)

Serdyukov, P. \& Serdyukov, P. (2017). Innovation in education: What works, what doesn ' $t$, and what to do about it? Journal of Research in Innovative Teaching \& Learning, 10 (1), 4-33.

Suharyadi, Nugroho, A., Purwanto, \& Faturohman, M. (2008) Kewirausahaan Membangun Usaha Sukses Sejak Usia Muda. Jakarta: Salemba Empat.

Tan, O. S. (2003). Problem-based learning innovation: Using problems to power learning in the 21st century. Singapore. Changage Learning.

Wesfix,T. (2017). Kreativitas Itu Dipraktekin. Jakarta: Gramedia.

Yew, E. H. J., \& Goh, K. (2016). Problem-based learning: An overview of its process and impacton learning. Healt Professions Education. ScienceDirect, 2, 75-79. 